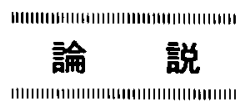

\title{
棒鋼の超音波信号処理システム
}

\author{
中村 薫*, 八木富一**, 福井和雄***
}

\section{Ultra-Sonic Signal Processing System of Steel Rod}

\author{
Kaoru Nakamura, Tomikazu Yagi \\ and Kazuo Fukui
}

\begin{abstract}
Synopsis
We planned the new manufacturing line of conditioning and inspecting of steel rod in 1983.

At that time, more correct and rapid judgement on results of ULTRA-SONIC TESTING on manufacturing line has been required to meet the increase of production. So, we developed "ULTRA-SONIC SIGNAL PROCESSING SYSTEM" using 16 bit micro -computer in 1984.

This system has following functions.

(1) The conditions of testing and standards of judgement exist in computer files and are updated interactively.

(2) The conditions of testing are set automatically to ULTRA-SONIC TESTER.

(3) This system displays the distribution of flaws and automatically marks the position of the flaws on the material by paint and furthermore notes the treatement following manufacturing process by comparing standards of judgement and echo signal intensity from ULTRA-SONIC TESTER.

(4) This system supervises to find something unusual in testing B-echo signal.

This paper introduces the outline of the "ULTRA-SONIC SIGNAL PROCESSING SYSTEM" in Chita Plant.
\end{abstract}

1.はじめに

大同特殊鋼 (以下, 当社という。) 知多工場大 型製品精整検查工程の合理化計画に伴い，設備の ライン化を実施した。同時に, ラインの工程管理・

昭和 60 年 7 月 29 日 受付

*大同特殊鋼秼知多工場

**大同特殊鋼姝中央研究所

***大同特殊鋼侏情報システム部
自動化を狙った計算機システム (LINCS) の開発 を行った。この LINCSの1サブシステムとして， マイクロコンピューターを利用して, 超音波探傷 検査の合否判定をオンラインで行う「超音波信号 処理システム』を開発した。

このシステムの概要を報告する。

\section{LINCS の概要}

LINCS (Large products INspection \& Conditioning control System)は, 棒鋼の冷却床払出し 


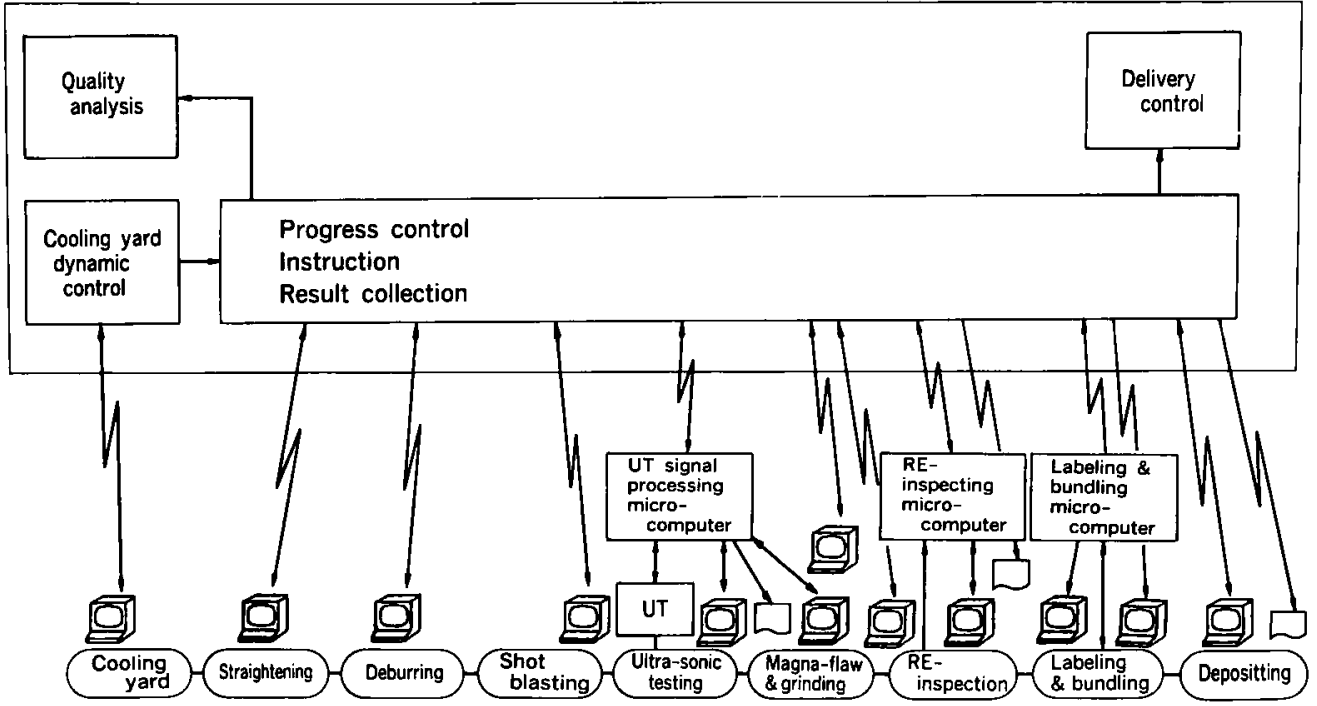

Fig. 1. Lincs constructon.

から入庫までの精整検査工程の進捗管理, 操業管 理および，仕掛管理を行らシステムである。操業 管理システムは作業命令の CRT 化 (ペーパーレ ス）および, マイコンの活用 ( 3 セット)による 自動化にも対応している。

Fig. 1 にLINCS のシステム構成を示す。

\section{3. 従来の検査方法と問題点}

従来の検査工程・設備は Fig. 2 に示すように, ハッチタイプであった。また，検査判定方法む， 一定レベル以上の久宿信号（アナログ信号）を検 知するのみであった。従って

（1） 久宿の有無は判定出来るが，欠陥位置及び 欠陥分布状態がつかめない。

（2）欠陷が発生すると，オフラインで手探傷 $\rightarrow$ 展開図（欠陷分布図）作成一合否判定を行わなけ ればならず，久陥信号の発生した棒鋼の処置を完 了するまでに多くの日数を要する。

(3) 品質データーの収集に多くの工数を要する ために，十分な品質水準の把握がなされない。 などの久点がありライン設備上での現品処置ある いは，品質水準の把握を阻害する要因となってい た。

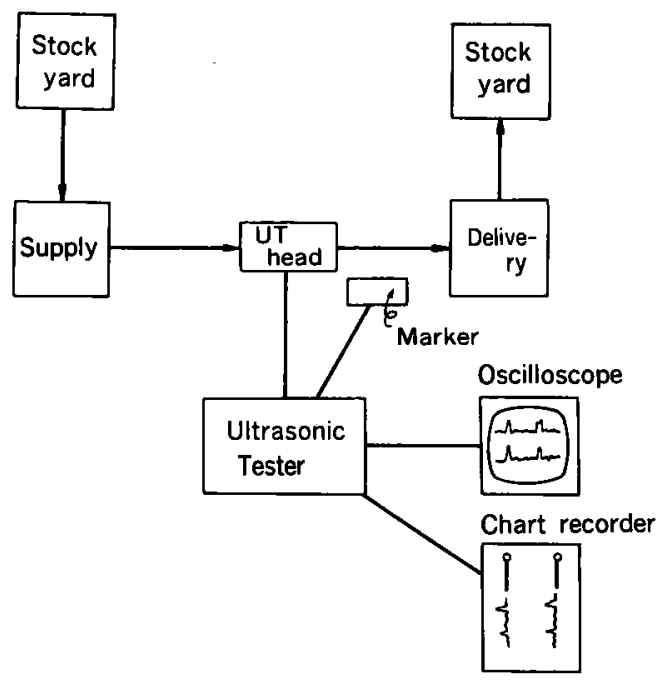

Fig. 2. Inspection process of old type.

\section{4. 超音波信号処理システムの概要}

\section{1 設 計 思 想}

ライン化された検査設備での超音波信号処理シ ステムの機能を決定する上で以下の点を考慮し た。

（1）探傷条件・判定基準をファイル化し，変更 を容易にすると共に，探傷時に自動的に設定出来 


\section{るよらにする。}

（2）棒鋼 1 本単位の欠陥発生場所・状況を捕之, 後工程へ判定結果 (切断・保留) 及び展開図を連 絡すると共に現品にもマーキングし，欠陌位置を 現品上で認識できるようにする。

（3）棒鋼 1 本単位の欠陥分布状態を指数化し, 品質水隼の把握を可能とする。

（4）探偒機の正常稼働を監視可能にする。

(5) 支障時間を短かくするために，キャリブレ ーションの自動化を行ら。

\section{2 システム棈成}

Fig. 3 にシステム構成図を示す。

今回のシステムは上位計算機↔超音波信号処理 用マイコン↔超音波探傷機のハイアラキー構造を 採っている。

上位計算機は主にライン全体のトラッキンク， 探傷条件・判定基準の管理，口ット単位の命令指 示，扣よび品質水準の把握を行っている。

超音波探傷機は，棒鋼 1 本単位の長さ方向徵小 区間単位の探傷信号の収集および記録計出力を行 っている。

超音波信号処理用マイコンは, 上位計算機から のロット単位の情報（探傷条件・判定基準）およ び超音波探傷機からの棒鋼長さ方向微小区間単位 の探傷信号を基に，合否判定，処置指示および指 数化を行っている。以下，超音波信号処理システ ム（以降マイコンといら）を中心に述べる。

\section{3 ハードウェア㩐成}

Fig.4にハードゥェア構成図を示す。

Intel 製の 16 ビットボードマイコンをべース に，上位計算機との接続および超音波探傷機から の高速データー収集に各々単独の CPU（8ビッ

ト）を採用した。

また, Intel 製以外のボードは，保守面を考虑し， 知多工場に多数設置されている当社高蔵製作所製 DAMIC-8の 8 ビットバス用ボードを採用した。

\section{4 ソフトウェア粠成}

Fig.5にンフトウェア構成图を示す。

OS Intel 標準のiRMX86 を使用した。アプ リケーションプログラムは一部高速処理が必要な 部分にはアセンブラ言語を使用し，大部分は PL/ Mを使用して開発した。

\section{5. 超音波信号処理システムの機能概要}

\section{1 探甥条件・判定基準管理}

棒鋼の材質，形状，サイズ別に超音波探傷条件 （探傷周波数，探傷感度等）扣よび合否判定・処 置基準（超音波探傷機からのエコー信号レベル弁 別，欠陥分布状態に基づく判定・処置基準）を標 準化し，上位計算機で管理している。この情報を 基に，マイコンではロット単位に探傷条件を自動 設定し，棒鋼 1 本単位の欠扸自動判定・処置指示 （切断・保留）を行い，上位計算機ではロット単 位の処置指示（ロット保留）を行っている。

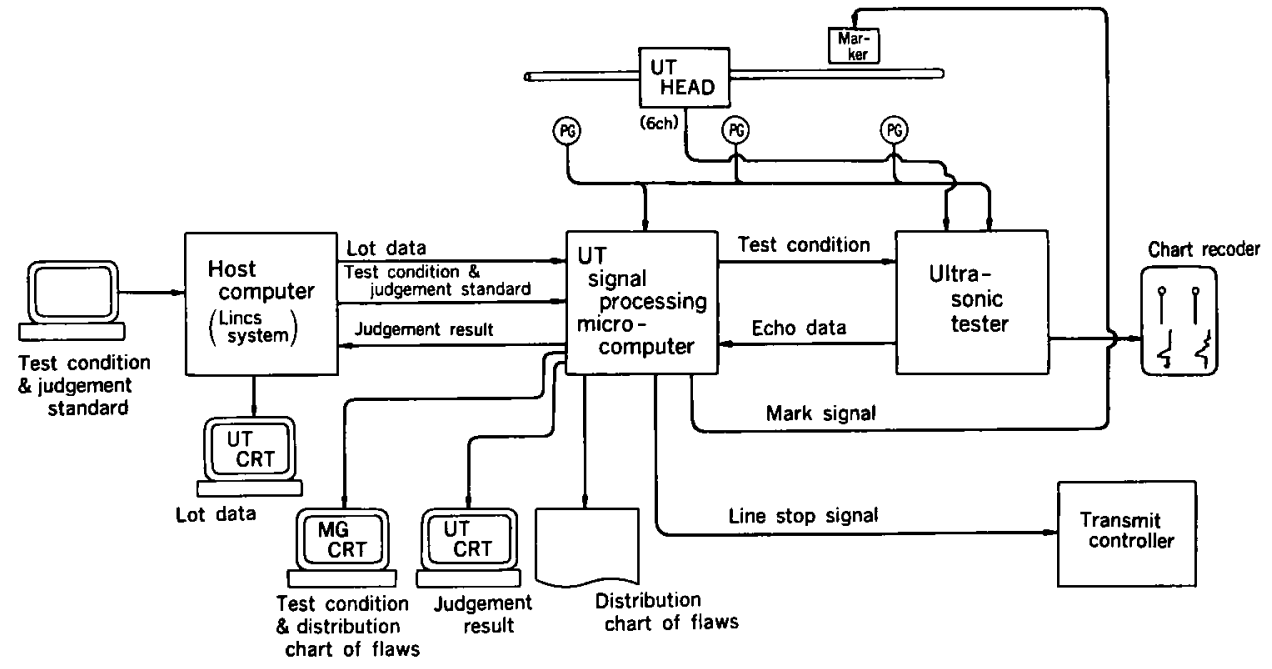

Fig. 3. System construction. 


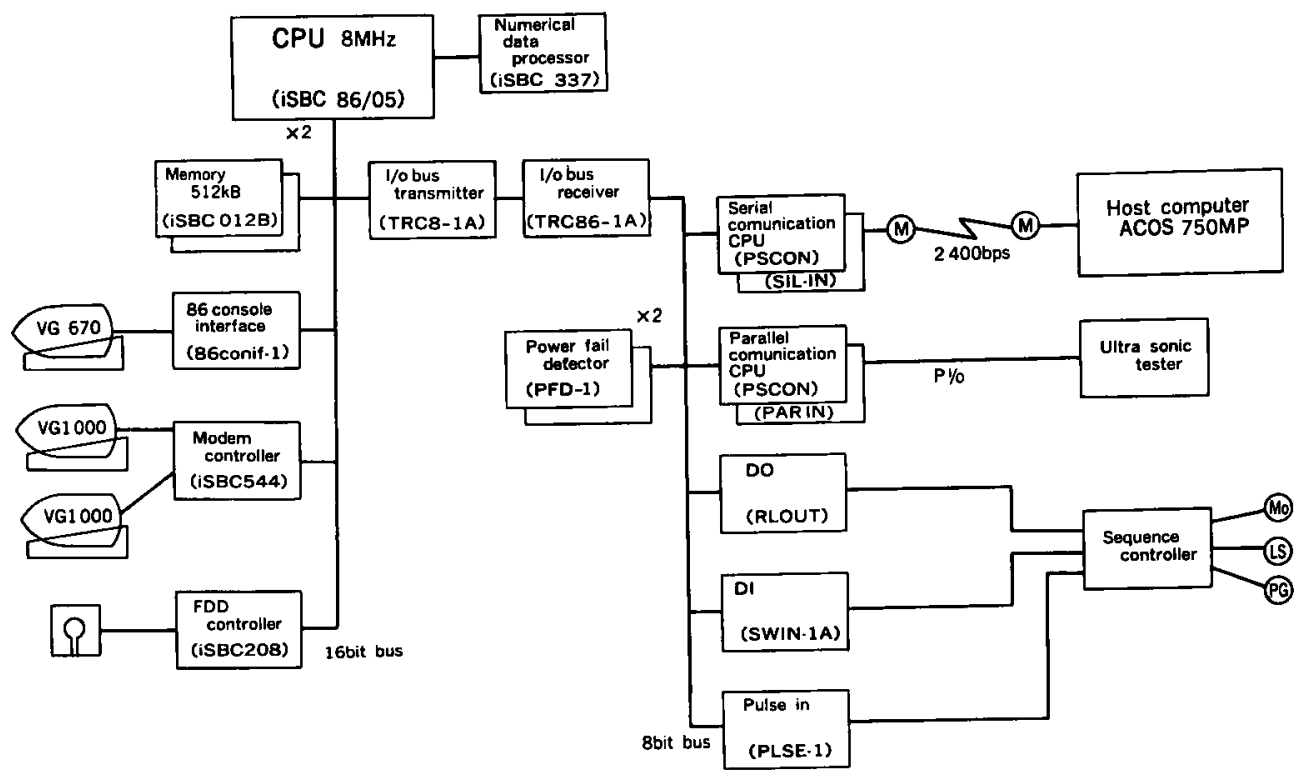

Fig. 4. Hardware construction.

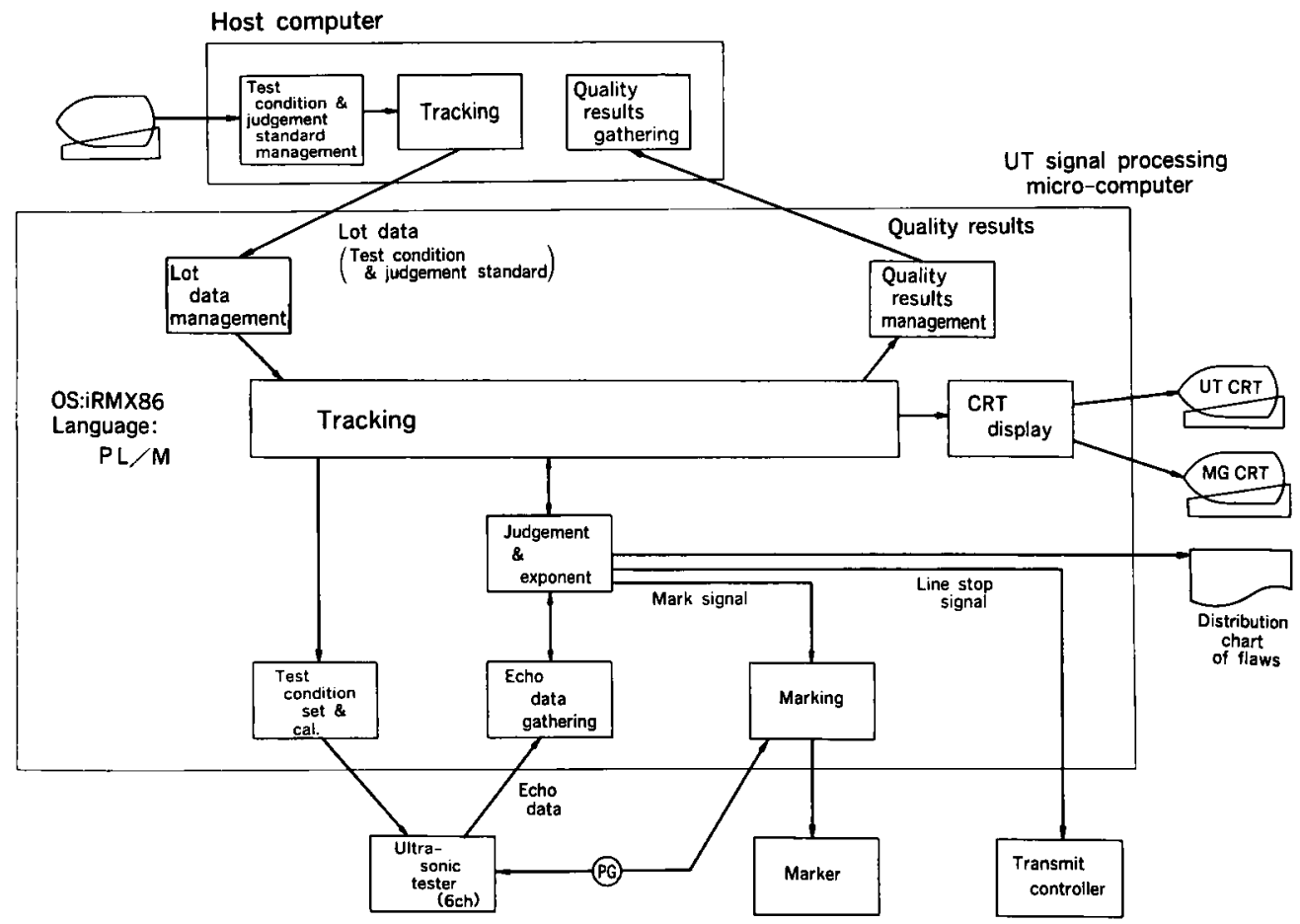

Fig. 5. Software construction.

\section{2 トラッキンク}

マイコンでは, ロット単位および棒鋼 1 本単位

のトラッキングを行い, 上位計算機では，ロット
単位のトラッキングを行っている。棒鋼 1 本単位 のトラッキングにより, 探傷条件の設定, 判定・ 処置，マーキング指示拉よびCRT 表示を行って 
いる。

5.3 探傷条件の自動設定および自動キャリ

$$
\text { フレーション }
$$

ロットの探傷開始前に, マイコンのCRTから 『ロット開始』を入力することにより，上位計算 機より口ット情報（探傷条件・判定基準等）がマ イコンへ伝送される。マイコンは，その情報に基 き，超音波探僎機へ探傷条件を自動設定する。そ の後, マイコンのCRTから『キ+リブレーション 開始』を入力することにより，超音波探傷機が自 動的にキャリブレーションを実行する。

キャリブレーションの内容は標準試験片の人工 欠陷または、底面エコーの大きさが，探傷条件で 与兄られた値になるよらに探傷機内の增幅器のゲ インを調節することである。

なお，このキャリブレーションは，ロットの途 中でる可能なよらにしてある。

\section{4 超音波探傷機エコー情報収集および判 定}

超音波探傷機より棒鋼長さ方向微小区間のエコ 一情報を収集する。この做小区間のエコー情報を， 上位計算機からの判定基準（16個の判定基準値） を基に，欠陥分布状態を認識し，合否判定・処置 指示（切断・保留）を自動的に行い，CRT 表示拉 よび現品へのマーク表示(切断ヶ所, 保留マーク) を行ら。

同時に，底面エコーの監視を行い，探傷異常の 自動検知，自動ラインストッブも行っている。

また, 微小区間の判定結果を小区間に集約し， 展開図として後工程 CRT への表示およびプリン ターへの出力を行っている。

\section{5 欠宿分布状態の指数化}

指数は棒鋼 1 本単位の徵小区間欠宿信号分布を 数値化したもので，展開図に表示すると共に，品 質実績データーとして，上位計算機へも伝送して いる。

\section{6 口ット判定}

上位計算機では，マイコンによる棒鋼 1 本単位 の判定結果を基に，ロット単位の保留判定した本 数比率を算出し，一定基準以上の場合はロット全 体を保留とする。

\subsection{CRT 表 示}

超音波探傷機扰よびこれに続く磁粉探傷機の運 転室に，口ット情報，探傷条件，判定結果を表示

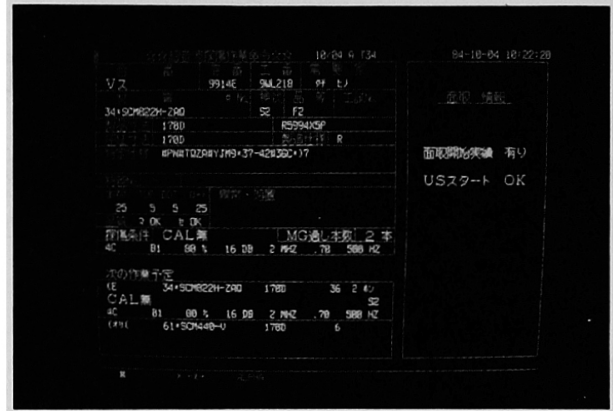

Photo. 1. Lot data (CRT display).

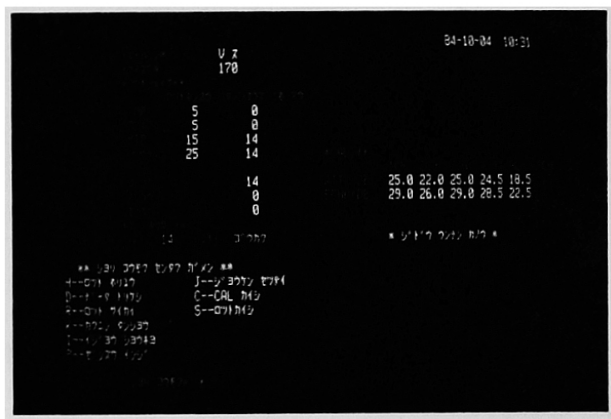

Photo. 2. Test condition of calibration (CRT display).

し, 確認探傷等の処置を容易にしている。Photo. 1 K上位計算機の口ット情報画面例を, Photo. 2 飞超音波探傷条件（Cal）画面を示す。

\section{6. 適用 結 果}

当社知多工場の大型製品精整検査ラインに適用 し、昭和59年 9 月 9 日より本番稼動した。

ライン化時の問題となっていたロット保留（オ フラインにて処理）の発生量は自動合否判定によ り従来の検查方法に比べ約 $1 / 5$ に減少させること ができた。また，所期の目的である品質保証，精 度の向上，高能率化などす満足させることができ た。

\section{7. む す ひ}

当システムの開発は，探偒条件，判定基準の整 理から始め, 検査部門，研究部門，情報システム 部の 3 部門協同で約 1 年をかけて開発した。

開発開始当初は，データーの整理に追われ，本 番近くでは，結果の検証等に多大な工数を費やし たが，現在は順調に稼働している。

今後は他の検查対象への適用拡大を図りたい。 